\title{
Literature Review on Low Carbon Eco-tourism
}

\author{
Yuyan Luo ${ }^{1, a}$, Jun Wang ${ }^{2, ~}{ }^{*}$, Qingzhong Dang ${ }^{1, \mathrm{~b}}$ and Yao Chen ${ }^{1, \mathrm{c}}$ \\ ${ }^{1}$ College of Management Science, Chengdu University of Technology, Chengdu 610059, China; \\ ${ }^{2}$ Business School, Sichuan Normal University, Chengdu 610101, China. \\ a luoyuyan13@mail.cdut.edu.cn, *Corresponding author Email: allen_wangjun@126.com, \\ b dangqingzhong@cdut.cn, ${ }^{\text {c}} 13438930799 @ 163 . c o m$
}

Keywords: Low carbon economy, low carbon eco-tourism, review.

\begin{abstract}
Climate change, resources and environment problems have aroused increasing academic attention around the world. In order to suppress ecosystem environment worsen, the ecological civilization construction has been started among the national world, therefore, the idea of low carbon and ecological development have emerged. For tourism industry, the development of tourism marks the progress of human civilization and it is also a major growth point of national economic development, however, it also has brought the phenomenon of the global climate warming, tourism environment worsening and so on. Thus, for the sake of according with the concept of sustainable development, how to combine the low carbon and ecological concepts, to develop low carbon eco-tourism and promote the transformation of the traditional tourism has become the hotpot. This article will review the related literature about low carbon eco-tourism from three aspects of low carbon economy, low carbon tourism, eco-tourism, so as to understand its development status and also point out low carbon economy eco-tourism in need of further research.
\end{abstract}

\section{Introduction}

With the progress of era, the social economy develops rapidly, and people's income level is gradually improving, people's consumption demands of the service products, especially the tourism product have been increasing day by day, therefore, the tourism industry is also developing fast. However, with the high benefits being brought to the tourism cities, the negative impact has been caused. In the year of 2008, the world tourism organization research report pointed out that the emissions of tourism development in 2005 was 1.3 billion, accounting for $4.9 \%$ of all emissions from human activities, and the contribution rate of global warming that caused by human factors, the whole tourism sector accounted for 5\%-14\% from the whole tourism sector [1]. Accelerating the development of tourism published by China's state council in 2009 put forward to develop tourism into a strategic pillar industry of national economy, promote energy conservation and environmental protection and advocate the way of low carbon tourism [2]. Besides, since 2002, Australia has issued the green globe 21 international eco-tourism standard to give a description of eco-tourism [3]. These show that the sustainable development of tourism industry has been being discussed as a highlight in the world, and experts and scholars studies on low carbon and ecological development of industry from different angles have made remarkable achievements.

This paper will review the related literature from three aspects of low carbon economy, low carbon tourism and eco-tourism to understand the current research progress and deficiency, and propose the research prospects of low carbon eco-tourism.

\section{Low Carbon Eco-tourism Research Status}

\subsection{Low Carbon Economy}

In 2003, the British government in its energy white paper our energy future: create a low carbon economy first mentioned the low carbon economy and pointed out that more economic output could be acquired through the less natural resources consumption and less environmental pollution [4]. Low 
carbon economy provides an opportunity to create a higher standard of living and a better quality of life and create opportunities for developing, using and outputting advanced technology; also, it can create new business opportunities and more chances of employment [5]. With the derivation of low carbon economy, its development pattern has been presented and international scholars have been discussing the low carbon economy. Foreign scholars' studies on it were earlier than the domestic researchers [6] and have been achieved comparatively abundant research achievements and the initial research mainly concentrated in a small number of industries, such as transportation, cement industry, etc. It shows that transportation released the largest carbon emissions of the OCED countries [7], and the cement industry was a major industry in greenhouse gas emissions [8]. So more researches focus on the national and global carbon emissions, such as the possibility of discussion that the U.K. and Germany respectively would achieve the target of $80 \%$ cut in carbon dioxide and the other greenhouse gases emissions based on those of 1990 in the middle of the century [9-10], the study of the causal relationship of the U.S. and Turkey's energy consumption, GDP and carbon emissions [11-12], the quantitative analysis of the relationship between energy consumption, carbon emissions and global GDP [13], the discussion on describing the methods of low carbon economy long-term development situation of city scale in Shiga, Japan [14], the determination of the population structure on the US and global carbon emissions [15-16], the direct relationship between the U.S. exports and the average international carbon emissions [17], the analysis and forecasting for the change of different parts of the temperature time series [18], and the adopted strategies in the process of transition to a low carbon future [19]. Besides, based on low carbon economy, some studies have discussed the relationship and influence of the climate changes, such as the relations between tourism and climate changes [20], the relationship between the climate and business economic thoughts and innovation [21], and the combination of re-industrialization and low carbon economy will help to mitigate climate change [22], using green performance score card to build green industry performance analysis [23], confirming the relationship of long-term and short-term between carbon emissions [24], etc.

Domestic studies on low carbon economy have been slightly later than abroad, and there're many literature involving low carbon economy or its related filed and having made a certain progress.

Since 2005, the discussions on facing challenges, possible ways and potential in the development of low carbon economy in our country have started [25] by analyzing the relations between the growth of GDP and carbon emissions, and we find that the main reason for the rise in greenhouse gas emissions is that our country relies too much on economic growth mode through investment and the industrial economic structure [26]. And the existing energy structure, energy efficiency, population and emissions intensity in china were at disadvantageous stage [27]. In view of energy consumption and carbon emissions in China, some studies have pointed out that measures should be taken from industrial structure adjustment, energy structure adjustment and innovation of science and technology [28], some analyzed the urgency of the development of low carbon economy in China from the aspects of greenhouse gas emission reduction pressure; energy security and resources and environment; and from the energy conservation priority, vigorously developing renewable energy, carbon funds, and establishing national carbon trading mechanism to put forward model of the development of low carbon economy policy measures in our country [29]. In 2009, on the basis of the review of the historical trajectories of the carbon emissions, Chinese academy of sciences sustainable development strategy research group explored the measures of China's response to climate change and low carbon development, and carried out the comprehensive assessment for China's sustainable development ability, resources and environment performance [30], and subsequent research was mainly around with the low carbon economy development mode, low carbon economy development elements, low carbon economy development ability differences, such as using developing gathered type of low carbon economy industry chain model, technology innovation and other means to promote and realize the transformation of economic development towards a low carbon economy [31]. The main factors affecting the development of low carbon economy have been extensive economic development, residents' low carbon consciousness and the lack of low carbon professional talents [32]. Low carbon technology was the core content to influence the low carbon development [33]. The 
ability of developing law carbon economy to show the diversity varied on the basis of different geographical [34]. Meanwhile, the studies carried out were about the low carbon economy development efficiency evaluation, low carbon economy development level and model, such as using AHP and grey correlation method to explore the low carbon economy development level [35-38], using a desirable output of SBM model to evaluate the efficiency of low carbon economy development [39], the obstacle, path and mode of tourism development under low carbon economy [40] and using the DPSIR model for construction of low carbon economy development index system [41].

As a whole, the researches on the low carbon economy have paid more attention to the macroscopic aspects, such as global, each country and even the regional development, however, the further research of bringing emissions in all areas is lacking, for instance, service-oriented organization and tourism scenic spots system of low carbon economy research is minor.

\subsection{Low Carbon Tourism}

Low carbon tourism development abroad started in 2000, and BCU advocated a kind of holiday footprint tool, and the tool was designed to provide a more useful or a wider range of sustainable development strategy under the background of "responsible tourism". Then many foreign scholars carried out findings about energy consumption, tourist behavior and carbon emissions of tourists, found that the different modes of travel, accommodation facilities and even the diet of tourists, affected the energy consumption of travel process [42]. And tourists have been responsible for global $\mathrm{CO}_{2}$ emissions, accounting for $4.4 \%$, which would continue to increase with an annual rate of $3.2 \%$ from 2005 to 2035 [43]. Tourism is a kind of important economic activities, both tourist consumption and waste emissions are more than local residents' daily amount [44]. Through investigation, most tourists were willing to get carbon offsets [45], but relying on carbon offsets exclusively, may hinder the sustainable development of tourism industry [46], so tourism industry stakeholders should recognize the consequence of environmental degradation, and provide strategic management for sustainable tourism practice [47].

Under the influence of low carbon travel abroad, the low carbon concept in all aspects of tourism in our country appeared, and the most typical event was that the first low carbon tour group made up of 10 Shanghai residents traveled in the North Pole successfully by their own expense in July 2009. Then the first low carbon tourism demonstration area appeared in Taiwan and Ma Ying-jeou took Taiwan's low carbon tourism ambassador, played a good role in promoting the prevalence of low carbon tourism in Taiwan. Ctrip pioneered carbon compensation plan firstly and encouraged travelers to use their own member points for saplings way to compensate for the carbon dioxide emissions. At present, the domestic researches on low carbon tourism mainly have focused on the induction of the basic situation of low carbon tourism and tried to encourage tourists to adopt this way of tourism, such as introducing the low carbon travel behavior from multiple angles in detail, advocating tourism to take positive countermeasures and transforming the mode of development [48], exploring the personal carbon footprint of visitors and low carbon travel behavior intention, predicting tourists' possible behaviors to the environment in the process of tourism activities, promoting and taking precautions before its behavior [49], advocating save energy and reduce pollution and with action to explain the construction of harmonious society, saving society and civil society through every link of eating, accommodation, transportation, traveling, shopping and entertainment [50]. By using low carbon technologies, applying mechanism of carbon sequestration and advocating low carbon tourism consumption mode, a higher quality of tourist experience and more tourism economic, social and environmental benefits can be obtained [51]. What has been said above has laid a foundation for the proposing and analysis of the low carbon tourism development mode [52]. Based on the concept, the follow-up research mainly started with the low carbon tourism development model, principles and dynamic of tourism development, carbon emissions, tourism traffic behavior and rural low carbon travel. For instance, according to problems diagnosing, goals setting, development principles, development strategy and performance evaluation of five steps constructed low carbon tourism development model [53]. Government regulation and control force, scenic areas endogenous power 
and market force were the motivation of low carbon scenic area [54]. Low carbon scenic spot should adhere to the principle of dynamics, coordinate resources, environment and human factors [55]. Tourism transport carbon emissions were full of the characteristics of high proportion, measuring difficultly, expanding area significantly and the more involved departments [56]. For tourists, social influence factors, cognitive factors, individual characteristics and self-adjustment factor would affect the low carbon travel behavior [57]. And the transformation and upgrading of rural low carbon development should be based on the reference of the experience of development of low carbon rural tourism at home and abroad, ensuring the direction and path of low carbon economic transformation and upgrading the rural tourism and building the upgrading of rural tourism theory model [58].

On the whole, the researches regarding low carbon tourism have placed emphasis on the relation of the country's carbon emissions, energy consumption and the mutual influence between them, and also gradually deepen in the study of the tourism industry of the carbon emissions associated with climate change and low carbon tourism concept, low carbon tourism exploration strategy, therefore, studies on visitors from more micro level in the tour of scenic spot in the process of carbon emissions influence and practice of low carbon tourism scenic spots to realize low carbon development needs to be further researched.

\subsection{Eco-tourism}

Eco-tourism is originated in the 1980s. After entering the 1990s, due to the ideas of sustainable development about natural, social, and economic coordination becoming the guiding idea to solve the problem of global environment, the corresponding eco-tourism has been developed rapidly. The data shows tourism was the world's fastest growing economy industry in the last century, among which eco-tourism was the fastest growing segment, and the average growth rate was from $15 \%$ to $20 \%$, which reflected the people restored its pristine state and advocate natural new fashion.

Foreign researches on eco-tourism began in the 1980s, special adviser Ceballos Lascurain of IUCN firstly put forward the concept of "eco-tourism" in 1983 [59]. At that time, this term was not used extensively, and some scholars still used natural ecosystem tourism or green tourism to express [60-61]. In 1987, WWF done a special study on five countries involved in Ecuador and published the research report on Eco-tourism: the Potential and Pitfalls. According to the definition of the first world congress on "tourism and environment", eco-tourism was aimed at appreciating and studying the natural landscape, wildlife and relating characteristic culture, by raising money for nature reserve to create employment opportunities for local residents and providing environment education for the public to contribute the conservation of nature tourism [62]. On this basis, further research would put forward by improving the whole social awareness of the value of the resources, building the atmosphere of protecting natural resources, expanding the foreign investment and capital input to achieve the purpose of the eco-tourism development on the natural environment protection [63], and try to implement the management strategy, make the ecological tourists experience pleasure and satisfaction from the original and transformed into a deeper understanding of comprehension, changing of attitudes, so as to implement responsible behavior for the environment [64], and helping people to better understand the ecological tourists frequently contact with nature environment, at the same time, exploring the social, economic, political and psychological mechanism of the impact on community eco-tourism [65]. Meanwhile, exploring the effects of the rural eco-tourism for residents, and proper political intervention were helpful to the residents in the ecological tourist area to transform the traditional the mode of farming, and acquire social-economic welfare[66], in addition, trying to keep balance on the relations between eco-tourism, tourism development and environmental protection [67].

With China's environment worsening, ecological damage problems in tourism development is more and more obvious, so many scholars pay close attention to eco-tourism, and a lot of researches focus on eco-tourism, eco-tourism and environmental pollution, etc. such as the research on developing eco-tourism was an inevitable choice for reasonable development and effective utilization of tourism resources in nature reserve [68], and pointed out that in the process of eco-tourism, due to the tourists behavior, service unit in scenic areas caused the environment problems of water pollution, 
solid waste pollution, noise pollution, vegetation destruction, and species reduction [69]. Besides, tourism ecological compensation has become a hot spot, and its meaning, interests subject, standards, and channels and mechanisms were the core content [70]. Based on this, the follow-up studies placed emphasis on eco-tourism resources, the construction of eco-tourism evaluation system, eco-tourism development mode and strategy, ecological civilization and eco-tourism and so on, such as artificiality and the objective existence of fragile eco-tourism resources were the internal cause of the fragility of ecological resources [71]. And it indicated that the construction of the evaluation system of eco-tourism resources should take tourism resources condition, ecological environment, tourism development conditions and development potential, degree of coordinated development into consideration [72]. Simultaneously, the government, tourism enterprises and the local community of the trinity of eco-tourism development mode can be constructed [73] and the ecological civilization was a factor to construct ecological tourism [74], and also community eco-tourism and rural tourism were the research emphasis, and some researchers thought that there existing some problems of eco-tourism management mode in the community, such as unsafe management mechanism, commercialized management thinking, the imbalance of the interests distribution and so on, therefore, its development can be conducted through government scientific management, the third party management and community autonomy management [75]. Rural eco-tourism in national regions should pay attention to building the national culture brand, eco-tourism industrialization, mobilizing more participants interactive cooperation, coordination of eco-tourism and rural construction to keep high effectiveness [76].

From what have been mentioned above, the study on eco-tourism mainly focused on ecological connotation of tourism, eco-tourism management strategy, the ecological environment and pollution, ecological compensation, eco-tourism development mode, eco-tourism evaluation system, eco-tourism resources and distinctive eco-tourism, etc. and it has achieved certain results, based on the protection of natural ecology, it takes sustainable tourism activities, consistent with the connotation of low carbon tourism nature and realization of the target, and the research about how to assess tourism scenic area development is deficient, considering advocating eco-tourism and low carbon tourism.

\section{Low Carbon Eco-tourism Development Prospects}

Through the review of the literature above, it is found that low carbon eco-tourism lacks the organic connection and integration of low carbon economy, low carbon tourism, eco-tourism regarding low carbon eco-tourism and has not formed a unified understanding on the notion and system of these.

Facing the arrival and development of low carbon economy and green economy, this paper argues that low carbon eco-tourism should be integrated with core ideas of energy saving and emission reduction and activities based on the nature, and it does not only embody the protection of the natural landscape development, but also reflect the measures taken to reduce carbon emissions with response to climate warming, and some combination of the two, that is, in the context of low carbon economy, we should draw on the idea of low carbon economy to develop low carbon eco-tourism and advocate for taking new tourism mode of low energy consumption, low pollution and management concept in the process of development and utilization of natural landscape. Promoting the low carbon eco-tourism way and reducing carbon emissions in the process of travel and management of scenic spots, tourist scenic spot's low carbonization development is the trend of the current and future. Based on the perspective of tourists, regulators, residents, systematic analysis and quantitative researches are still lacking on building the relations of low carbon eco-tourism and the construction of low carbon scenic area and embodying the influence of low carbon economy in all levels in the construction process of scenic area. 


\section{Conclusions}

According to the review of the related researches of low carbon economy, low carbon tourism and eco-tourism, a basis of the low carbon eco-tourism will be set in the further studies for the ecological civilization and low carbonization of tourism industry. Under the atmosphere with climate change and environmental pollution, low carbon eco-tourism development helps to alleviate the pressure of the scenic area, promote the sustainable development of tourism industry and contribute to the process of the construction of ecological civilization, and encourage people to know nature, enjoy nature, and protect nature. In addition, the low carbon eco-tourism accords with energy conservation and environmental protection concept and corresponds to the development of circular economy concept, and it has a positive role to promote the development of tourism.

\section{Acknowledgments}

This work was supported by the Major International Joint Research Program of the National Natural Science Foundation of China (Grant no. 71020107027), the National Natural Science Foundation of China (Grant no. 71501019, 71501138, 71601164 and 71371130), Youth Program of Social Science Research of Sichuan Province for the Twelfth Five-year Plan (Grant no. SC15C005 and SC15C030), General Program of Education Department in Sichuan Province (Grant no. 16SB0071 and 16SB0049), General Program of Mineral Resources Research Center in Sichuan Province (Grant no. SCKCZY2014-YB04 and SCKCZY2013-YB006). And Jun Wang is corresponding author.

\section{References}

[1] Programme, United Nations Environment. Climate change and tourism: responding to global challenges, Climate Change \& Tourism Responding to Global Challenges 12. 4 (2008) 168-181.

[2] The state council, The state council about accelerating the development of tourism, Liaoning province people’s government gazette 34 (2009) 6-10.

[3] L. Zhou, On the necessities, feasibilities and principles of establishing China's national eco-tourism standard, Journal of China University of Geosciences (Social Sciences Edition) 1 (2006) 56.

[4] U.K. Energy White Paper 2003: Our Energy Future: Creating a Low-carbon Economy, London, 2003.

[5] N.Y. Yuan, Concept and connotation of low-carbon economy, Urban Environment \& Urban Ecology 23. 1 (2010) 43-46.

[6] X.G. Yin, H. Ting, A synthesis of foreign scholars' research on low carbon economy, China Population, Resources and Environment 20. 9 (2010) 18-23.

[7] M. Marco, The economics of the greenhouse effect: evaluating the climate change impact due to the transport sector in Italy, Energ. Policy 28. 13 (2000) 957-966.

[8] Rehan, R., and M. Nehdi. Carbon dioxide emissions and climate change: policy implications for the cement industry, Environ. Sci. Policy 8.2 (2005) 105-114.

[9] D. Johnston, R. Lowe, M. Bell, An exploration of the technical feasibility of achieving carbon emission reductions in excess of 60\% within the UK housing stock by the year 2050, Energ. Policy 33. 13 (2005) 1643-1659.

[10] D.J. Treffers, APC Faaij, J. Spakman, A. Seebregts, Exploring the possibilities for setting up sustainable energy systems for the long term: two visions for the Dutch energy system in 2050, Energ. Policy 33. 13 (2005) 1723-1743. 
[11] Soytas, Ugur, R. Sari, B. T. Ewing, Energy consumption, income, and carbon emissions in the United States, Ecol. Econ. 62.3 (2007) 482-489.

[12] Soytas, Ugur, R. Sari, Energy consumption, economic growth, and carbon emissions: Challenges faced by an EU candidate member, Ecol. Econ. 68.6 (2009) 1667-1675.

[13] R. Ramanathan, A multi-factor efficiency perspective to the relationships among world GDP, energy consumption and carbon dioxide emissions, Technol. Forecast. Soc. 73.5(2006):483-494.

[14] K. Shimada, Y. Tanaka, K. Gomi, Y. Matsuoka, Developing a long-term local society design methodology towards a low-carbon economy: An application to Shiga Prefecture in Japan, Energ. Policy 35. 9 (2007) 4688-4703.

[15] M. Dalton, B. O'Neill, A. Prskawetz, L. Jiang, J. Pitkin, Population aging and future carbon emissions in the United States, Energ. Econ. 30. 2 (2008) 642-675.

[16] S. Puliafito, J. Puliafito, M. Grand, Modeling population dynamics and economic growth as competing species: An application to $\mathrm{CO}_{2}$, global emissions, Ecol. Econ. 65.3 (2008) 602-615.

[17] P. Stretesky, M. Lynch, A cross-national study of the association between per capita carbon dioxide emissions and exports to the United States, Soc. Sci. Res. 38.1 (2009) 239-250.

[18] F. Viola, S. Paiva, M. Savi, Analysis of the global warming dynamics from temperature time series, Ecol. Model. 221. 16 (2010) 1964-1978.

[19] P. Söderholma, R. Hildingssonb, B. Johanssonc, J. Khanc, F. wilhelmssond, Governing the transition to low-carbon futures: A critical survey of energy scenarios for 2050, Futures 43.10 (2011) 1105-1116.

[20] S. Gssling, D. Scott, M. Hall, Challenges of tourism in a low-carbon economy, Wiley Interdisciplinary Reviews Climate Change 4. 6 (2013) 525-538.

[21] K. Kaesehage, M. Leyshon, C. Caseldine, Communicating climate change - Learning from business: Challenging values, changing economic thinking, innovating the low carbon economy, Fennia 192. 2 (2014) 81-99.

[22] S. Lechtenbhmer, C. Schneider, M. Roche, S. Höller, Re-industrialisation and low-carbon economy-can they go together? results from stakeholder-based scenarios for energy-intensive industries in the German State of North Rhine Westphalia, Energies 8.10 (2015) 11404-11429.

[23] H. Hashimab, S. Bakara, J. Lim, Green industry for low carbon economy: palm oil green assessment tool, Energy Procedia 61 (2014) 2759-2762.

[24] A. Ahmad, Y. Zhao, M. Shahbaz, S. Bano, Z. Zhang, S. Wang, Y. Liu, Carbon emissions, energy consumption and economic growth: An aggregate and disaggregate analysis of the Indian economy, Energ. Policy 96 (2016) 131-143.

[25] G. Zhuang. The low carbon economy development path and potential analysis, Studies in International Technology and Economy 83 (2005) 9-13.

[26] Z. Wang, L. Wang, Economic growth and its effects on carbon emission in China, Journal of Safety and Environment 6.5 (2006) 88-91.

[27] Y. Zhou, J. Zou, The impact factors of low-carbon economy development and countermeasure thought for China, Statistics \& Decision 23 (2009) 99-101.

[28] Y. Jin, Y. Wang, S. Hao, B. Zhu. Low carbon economy: idea, application, innovation, Engineering Sciences 10. 9 (2008) 4-13.

[29] Y. Fu, Y. Ma, Y. Liu, W. Niu, Development patterns of low carbon economy, China Population, Resources and Environment18. 3 (2008) 14-19. 
[30] Sustainable development strategy research group of Chinese academy of sciences, China sustainable development strategy report 2009 - China's approach towards a low carbon road future, Science Press, Beijing, 2009.

[31] C. Xu, Low carbon economy and China's economic development path, Management World, 7 (2010) 171-172.

[32] C. Liu, T. Zhao, Research on development of China's low-carbon economy in 2020, China Population, Resources and Environment 21.7 (2011) 77-83.

[33] C. Liu, Y. Yang, Study on reality restriction and regulation policy of China's low carbon economic development, Journal of Southwest University for Nationalities(Humanities and Social Science) 34.1(2013):157-161.

[34] Z. Zhang, W. Shi, Z. Lu, Research on the regional difference of low-carbon economic development capability in China, East China Economic Management 1 (2013) 60-64.

[35] X. Li, X. Li, D. Wang, Study on low carbon economy development evaluation in Hebei province based on DPSIR, Journal of Hebei University of Economics and Business 35. 2 (2014) 106-109.

[36] Q. Yu, X. Dong, C. Liu, Analysis of low carbon economy development level in the five northwestern provinces of China, Resource Development \& Market 30.4 (2014) 434-437.

[37] H. Yang, L. Li, J. Liu, Low carbon economy development level and industry differences of manufacturing in China: the grey relation projection method comprehensive evaluation based on entropy weight, Forum of World Economics \& Politics 2 (2014) 147-162.

[38] J. Qin, M. Tang, X. Liu, The grey comprehensive evaluation on the development of low-carbon economy, Ecological economy 30. 4 (2014) 14-18.

[39] D. Jia, J. Huang, Regional differences and factors affecting the efficiency of low-carbon economy, Journal of Lanzhou University (Social Science) 42.4 (2014) 113-119.

[40] Y. Pan, The new tourism development mode in Wuxi under the background of low carbon economy, China Business Theory 13(2016) 102-104.

[41] M. Lin, C. Deng, B. Xie, B. Liu, G. Lei, Evaluation on the level variation of low-carbon economy development of Changsha City based on the DPSIR Model, Research of Agricultural Modernization 37. 3 (2016) 1-7.

[42] S. Becken, D. Simmons, C. Frampton, Energy use associated with different travel choices, Tourism Manage. 24. 3 (2003) 267-277.

[43] P. Peeters , G. Dubois, Tourism travel under climate change mitigation constraints, Journal of Transport Geography 18. 3 (2010) 447-457.

[44] N. Kuo, C. Lin, P. Chen, Y. Chen. An inventory of the energy use and carbon dioxide emissions from island tourism based on a life cycle assessment approach, J. Clean. Prod. 17. 15 (2009) 1324-1330.

[45] C. Mclennan, S. Becken, R. Battye, K. So, Voluntary carbon offsetting: Who does it?, Tourism Manage. 45 (2014) 194-198.

[46] D. Scott, S. Gössling, C. Hall, P. Peeters, Can tourism be part of the decarbonized global economy? The costs and risks of alternate carbon reduction policy pathways, J. Sustain. Tour. 24.1 (2015) 1-21. 
[47] A. Michailidou, , C. Vlachokostas, N. Moussiopoulos, A methodology to assess the overall environmental pressure attributed to tourism areas: A combined approach for typical all-sized hotels in Chalkidiki, Greece, Ecol. Indic. 50.50 (2015) 108-119.

[48] G. Xiao. Advocate low carbon travel. Proceedings of Zhejiang tourism industry innovation and development (2008) 56-58.

[49] S. Chen, Research on carbon footprint and low carbon tourism behavioral intention: a case study of Pinlin town, Feng Chia University, 2009.

[50] X. Liu, Research on low-carbon economy and low-carbon tourism, China's collective economy 13 (2009) 154-155.

[51] M. Cai, Y.Wang, Low-carbon tourism: a new mode of tourism development, Tourism Tribune 25. 1 (2010) 13-17.

[52] R. Guo, Study on low-carbon tourism development model of alpine wetland: a case study of the First Bend of the Yellow River, Technology and Market 1 (2013) 89-91.

[53] D. Zhu, Y. Zhou, Construction on the low-carbon tourism development mode in national historical and cultural town: a case study of Liye town, Longshan County, Changsha province, Science and Technology Entrepreneurship Monthly 29. 9 (2016) 1-3.

[54] T. Wang, Research on low-carbon development path and model of tourist attraction: a case study of tourist attractions in Baguazhou scenic area of Nanjing, Toursim Overview 10 (2014) 171-173.

[55] F. Zhu, Construction planning and design strategies of low-carbon tourism scenic area, Business 43 (2015) 273-273.

[56] J. Sun, J. Zhang, G. Tang, H. Hu, M. Chen, Tourist traffic emissions research progress and enlightenment, China Population, Resources and Environment 26.5 (2016) 73-82.

[57] C. Liang, X. Li, Construction of low-carbon tourism behavior model based on influencing factor analysis, Journal of Shandong University of Finance and Economics 28.3 (2016) 69-76.

[58] Q. Chen, Z. Chen, Promoting the low-carbon development of rural tourism, researching transformation and upgrading of rural tourism in Beijing under the background of the low-carbon economy, Issues in Agricultural Economy 5 (2016) 98-100.

[59] L. Ceballos, The future of ecotourism, Mexico Journal 1 (1987) 13-14.

[60] D. Fennell, P. Eagles, Ecotourism in Costa Rica: a conceptual framework, Journal of Park \& Recreation Administration 6. 3 (1990) 23-34.

[61] M. Miller, The rise of coastal and marine tourism, Ocean coast. Manage. 20. 3 (1993) 181-199.

[62] Editorial committee of China's agenda in the 21st century, China's agenda in the 21st century, China Environmental Science Press, Beijing, 1994.

[63] M. Filani, The role of national tourist associations in the preserving of the environment in Africa, Journal of Travel Research 13. 4 (1975) 7-12.

[64] M. Orams, Towards a more desirable form of ecotourism, Tourism Manage. 16.1 (1995) 3-8.

[65] R. Scheyvens, Ecotourism and the empowerment of local communities, Tourism Manage. 20. 2 (1999) 245-249.

[66] R. Hashim, Z. Latif, F. Merican, N. Zamhury, The Praxis of Langkawi's sustainable regeneration strategy through eco-tourism, Procedia - Social and Behavioral Sciences 170 (2015) 49-57. 
[67] A. Mathis, J. Rose, Balancing tourism, conservation, and development: a political ecology of ecotourism on the Galapagos Islands, Journal of Ecotourism 15. 1 (2016) 1-14.

[68] J. Zhang, B. Xu, M. Huang, The problems and countermeasures for developing eco-tourism in Chinese nature reserves, China Forestry Business 1 (2005) 19-22.

[69] Y. Zhao, X. Yang, H. Si, Discussion on the main environmental problems and solutions of the eco-tourism, Environmental Protection and Circular Economy 29. 7 (2009) 50-54.

[70] M. Liu, C. Lu, Z. Hu, Tourism ecological compensation: connotation and related scientific issues, TourismTribune 28. 2 (2013) 52-59.

[71] Q. Lin, Low-carbon tourism development evaluation and suggestion in Songshan, Henan Science 33. 11 (2015) 2065-2070.

[72] P. Dai, J. Hou, Construction and Empirical of Eco-tourism resources evaluation system: a case study of Zhangjiajie, Market Forum 10 (2014) 68-71.

[73] Z. Yao, F. Yuan, Y. Wu, Z. Xin, C. Yang, Discussion on development model of ecotourism for lake Poyang-Nanji wetland in Jiangxi, Jiangxi Science 33. 1(2015) 126-132.

[74] X. Zhang, Y. Wang, G. Yang, P. Li, The definition of ecological civilization tourism and industrialization, Ecological economy 32. 6 (2016) 209-213.

[75] J. Ni, Some thoughts of the community eco-tourism management mode, Journal of Chuzhou University 18. 3 (2016) 79-82.

[76] W. Zhao. Analyzing the combination of rural eco-tourism development and the new rural construction in national regions, Fujian Agriculture 8 (2015) 2. 